\title{
Religious Education and the Challenge of Modernity
}

\author{
Tengku Ahmad Hazri*
}

Religious education today confronts modernity in more complex ways than is readily acknowledged. The flourishing of Islamic educational establishments in the West the newly-founded Cambridge Muslim College in the United Kingdom and Zaytuna College in the United States come to mind - inevitably raises fundamental questions pertaining to Muslim religiosity. The survival of religious education distinct from the modern one is, so the criticism goes, suggestive of the failure of Islam to come to terms with modernity, as it clings resiliently to the relic of a bygone era. At the other end of the spectrum, Muslims often express their dismay at the failure of modern education to address their spiritual needs. It was Seyyed Hossein Nasr (b. 1933) - Professor of Islamic Studies at George Washington University in the United States, one of the world's foremost Islamic philosophers and a renowned scholar of comparative religion - who once lamented over the ease with which modern education instils doubt in the faith of the Muslims. Is reconciliation then possible? We think in the affirmative, and the solution is to be found by inquiring into the philosophical underpinnings that support these systems.

A glimpse at the forms of education of the two may hint at their theoretical foundations. Religion represents tradition; its province is chiefly the permanent and immutable aspects of man and reality while modernity addresses the constantly evolving and dynamic domains of life. That there are differences between the two is easily reflected in the form of education, and we will, for the purpose of the present discourse, highlight three main features. Firstly, traditional education assumes the form of a master-disciple relationship while the modern prizes independence of judgment amidst a plurality of opinions. Secondly, the intellectual outlook of traditional education is often inter-disciplinary while that of the modern values specialisation. Thirdly, there are substantial differences between what traditional education views as the most 'basic' or 'elementary' knowledge and the modern understanding of it. The possibility of reconciliation is only secured if a genuine synthesis between the two can be brought about, which in turn necessitates a discussion on the epistemological significance of these differences, and to this we now turn.

At first sight, the traditional education system of which Islamic religious education is a fine example may seem anachronistic by modern standards. Yet Islam is certainly not alone in this respect. The classical system in which a master-

* Tengku Ahmad Hazri is a Research Assistant at IAIS Malaysia. 
disciple relationship is dominant is found even in other civilisations - one may think of Aristotle's relationship to Plato or Plato's loyalty to Socrates in the Greek tradition. This mode of education relies on a single teacher who imparts knowledge to the student in a diverse range of disciplines. Often it involves heavy emphasis on rote-learning and memorisation much abhorred by modern educational practice. It is common for a student of the traditional Islamic sciences to be required to know by heart thousands of ahädith as part of the naqli curriculum. What, the modern may lament, is the value of this component given the ease with which such information may be acquired? Independence of judgment may only be nurtured if the student is exposed to a multitude of opinions, leaving the task of weighing their relative worth to be decided on his own. Yet one may consider if the two are really mutually exclusive alternatives. Traditional thought affirms degrees or hierarchy of selfhood - a view that psychoanalysis does not altogether discount and hence the mind could generate thought, acting upon what is known through memory, quite independently of subjective consciousness, only to surface to this level later as 'intuitions'. As the Arab polymath Ibn Khaldūn (d. 1406) once observed, the quality of one's writing depends on the quality of memorised material. To this one may add a further component: the traditional education system is built upon the assumption that knowledge is ultimately inseparable from its source. The manifold disciplines which a teacher may master reflect but his vision of an aspect of reality that, in an intellectual climate that insists on the ultimate unity of things, crystallises itself in the numerous 'disciplines'. Consequently the scholar's 'physics' is intricately bound to his 'metaphysics', 'cosmology' and 'epistemology'. The eighteenth-century scholar Shah Wali Allah is a fine example of this trend, whose 'dialectical' philosophy of reconciliation and synthesis is applied across the disciplines - in metaphysics via the reconciliation wahdat al-wujüd (Panentheism, lit. 'unity of being') and wahdat al-shuhüd (Apparentism, lit. 'unity of perception'); in epistemology through the theory of the unity of knowledge; and in jurisprudence as the synthesis of the various schools of law. To divorce the 'idea' from the source, as in modern practice, is tantamount to de-contextualisation of knowledge which risks distortion and false understanding. Nevertheless such an approach is crucial where what is at stake is less the truth itself than its utility, an element which, however, is not to be underestimated.

The second component of traditional education has to do with its inter-disciplinary nature, i.e. a single scholar may master simultaneously the different branches of learning, remaining faithful to one intellectual strand that reflects his intellectual affiliation. What is 'specialised' thus is not the discipline but the 'point of view' - akin to contemporary trend that now marches steadily towards ideologicallydriven epistemology rather than discipline-oriented (e.g. 'feminist epistemology', 'feminist jurisprudence, criminology', etc.). That this is so has to do with the fact 
that tradition values universals while modernity emphasises particulars. Analytical thought so typical of modern learning sees the constitutive units that make up the final unit. In other words, once an aspect of reality is grasped intuitively, its rational application across the disciplines as far as traditional thought is concerned can be realised. Again, the two may complement one another rather than be juxtaposed as antagonists. Religious education today can incorporate modern thought insofar as the very idea of "religion" is precisely meant to allow the possibility of transcendent, metaphysical truth attained intuitively to be lived and understood even at a rational, ordinary level of consciousness. The classical dichotomy of Islamic philosophers between 'rational or acquired knowledge' ('ilm al-hussuulli) and 'presential knowledge' ( $\mathrm{ilm}$ al-hudūrì) need not be seen as bipolarity, rather as continuum.

The third feature that we wish to discuss is different conceptions of what is 'basic' or 'elementary' knowledge between the two educational systems. During a public lecture on Religion and Global Politics held at the International Institute of Advanced Islamic Studies (IAIS) Malaysia in 2009, the American scholar Richard Falk diagnosed the 'conflict' between religion and modernity as a clash between two knowledge-systems - the one firmly metaphysical while the other anti-metaphysical. Religious education then accords immense importance to metaphysical knowledge as the basis and foundation of other knowledge. Within the specifically Islamic context, this means that the sole source for such knowledge - Revelation - is made to be the prelude to the other sciences. This is why knowledge of the Qur'ān and the hadith constitutes the twin-pillars of the traditional religious sciences. Classical Islamic philosophers - be they a Peripatetic such as al-Fārābī (d. c.950), a theologian and Sufi such as al-Ghazālī (d. 1111), or an Illuminationist such as Quṭb al-Dīn al-Shīrāzī (d. 1311) - invariably held knowledge of God as the highest pursuit in their classification of knowledge. It is possible nonetheless to absorb 'modern' knowledge having laid down the metaphysical framework within which the 'secular' sciences can be interpreted and, subsequently, indigenised as part of, if not native to, the Islamic intellectual tradition, through well-articulated schemes of hierarchy and classification of the sciences.

The preceding discussion ought not to be seen as mere theoretical quibbles. The workability of its central claims and hypotheses can be realised as far as the design of curriculum content is concerned. To begin with, institutions must invariably incorporate the study of the Qur'ān and hadith as basic knowledge for the student, which may be graduated from an initial presence as a distinct subject, elaborating especially on the fundamental knowledge, i.e. regarding the nature of man, religion, God, society, etc. This should equip the student with the metaphysical-revelatory knowledge through which modern sciences and knowledge may be understood. Yet this is certainly insufficient if the intuitive vision and spirit have not been nurtured. For this reason, emphasis ought to be given to, at least initially, a single 
scholar, with all his dominions of knowledge, to insinuate within the student the ability of grasping the unity of knowledge with its divergent application. A comprehensive text that demonstrates such organic unity, in which socio-political thought and other peripheral inquiries are but extensions of principal knowledge (e.g. metaphysics), such as Shāh Walī-Allāh's (d. 1762) Hujjat Allāh al-bālighah or al-Budūr al-bäzighah could be made central to learning. The purpose here is to inculcate the ability to 'specialise' in that point of view, as an aspect of reality, after which the mastery of 'disciplines' can be facilitated.

The said suggestion can be implemented on a gradual basis, beginning perhaps at the university level, after which it can be custom-tailored to suit the demands of secondary and later perhaps primary education, in conformity with the different levels of understanding. Modern knowledge should not be hostile to religious education, but rather its friend and ally. 